\title{
PENERAPAN METODE DISKUSI BERBANTUAN LKS UNTUK MEMPERBAIKI KEMAMPAUN PSIKOMOTORIK SISWA PADA MATA PELAJARAN MATEMATIKA KELAS VIII-2 SMP NEGERI 4 MEDAN
}

\author{
Elza Yeni \\ Guru Matematika Kelas VIII-2 SMP Negeri 4 Medan \\ Surel : elza_yeni02@gmail.com
}

\begin{abstract}
Abstrak
Penerapan LKS bertujuan meningkatkan kualitas pelaksanaan pembelajaran yang berorientasi pada setiap hasil belajar siswa. Hasil belajar psikomotorik siswa terjadi peningkatan yang menurut pengamatan pengamat pada Siklus I dan II antara lain mengidentifikasi maksud pembicaraan $31 \%$ menjadi 59\%, menggunakan tata bahasa yang tepat $32 \%$ menjadi $60 \%$, berbicara secara jelas dan mudah dimengerti $22 \%$ menjadi $53 \%$, menggunakan pilihan kosakata yang tepat $33 \%$ menjadi 59\%, dan yang Intonasi suara sesuai dengan yang disampaikan $23 \%$ menjadi $57 \%$. Peningkatan hasil belajar afektif siswa pada Siklus I dan II antara lain sikap kejujuran $26 \%$ menjadi $58 \%$, disiplin $30 \%$ menjadi $54 \%$, tanggung jawab $28 \%$ menjadi $56 \%$, ketelitian $32 \%$ menjadi $54 \%$, dan kerja sama $24 \%$ menjadi 56\%. Pada Siklus I rata-rata nilai tes 77 dengan ketuntasan pembelajaran sebesar $64 \%$ dan pada Siklus II rata-rata nilai tes 86 dengan ketuntasan pembelajaran naik menjadi $91 \%$.
\end{abstract}

Kata Kunci : Hasil Belajar, Kemampuan Psikomotorik

\section{PENDAHULUAN}

Pembelajaran Matematika haruslah lebih berkembang, tidak hanya terfokus pada kebiasaan dengan strategi atau urutan penyajian sebagai berikut: diajarkan definisi, diberikan contoh-contoh dan diberikan latihan soal. Namun hasil perolehan nilai beberapa mata pelajaran dalam kenyataannya masih ada yang belum memenuhi standar, tidak terkecuali untuk mata pelajaran Matematika. Salah satu faktor penyebabnya adalah latihan soal umumnya jarang sekali berbentuk soal cerita yang berkaitan dengan terapan
Matematika dalam kehidupan
sehari-hari. Oleh karena itu sangat
memungkinkan siswa telah
mengalami karena cenderung
tidak berasosiasi dengan
pengalaman sebelumnya.
Fenomena dibanyak sekolah ini, terjadi pula pada SMP Negeri 4 Medan. Beberapa hal yang lazim terjadi pada pembelajaran Matematika di SMP Negeri 4 Medan adalah pembelajaran masih monoton. Meski peneliti sebagai guru telah mengenal model-model dan ragam metode pembelajaran tetap 
saja pemahaman peneliti dalam menerapkan model maupun metode secara praktis masih terbatas, sementara kebutuhan akan variasi model sangat mendesak. Interaksi belajar mengajar antara guru dan siswa termasuk lemah dalam pengertian bahwa pembelajaran tidak melibatkan siswa secara aktif untuk berinteraksi dengan sumber belajar dalam pembelajaran. Alasannya adalah kebutuhan sumber belajar dan perangkat pembelajaran yang masih terbatas untuk melaksanakan pembelajaran berorientasi siswa aktif. Guru tidak ubahnya seperti pendongeng cerita, yang akan berakhir dengan soal atau pertanyaan dan seolaholah tidak begitu bermakna. Hal yang menyebabkan kegiatan konsultatif antara guru dan siswa untuk menyelesaikan soal-soal yang berkategori sulit jarang terjadi.

Sementara itu, Matematika masih dianggap sebagai pelajaran yang sulit akibat kurangnya pengaplikasian setiap materi kedalam kehidupan sehari-hari siswa. Siswa-siswa SMP Negeri 4 Medan seringkali masih merasa kesulitan, ragu-ragu, agak takut dan kuatir salah jika menjawab pertanyaan dari guru dan terlebih lagi siswa malu untuk bertanya. Hal ini salah satu hal yang menyebabkan disetiap jam pelajaran Matematika siswa cenderung merasa enggan dan malas. Keadaan ini jika dibiarkan

maka nilai pelajaran Matematika akan semakin menurun dan gagal dalam memperoleh nilai ketuntasan minimal yang telah ditentukan. Untuk mengatasi masalah tersebut seorang guru harus mampu memberikan motivasi terhadap siswa melalui pengelolaan kelas yang menarik dan melibatkan siswa dalam menemukan konsep.

Selain itu perlu juga diupayakan langkah-langkah yang dapat dilaksanakan baik oleh siswa maupun guru. Bentuk dari tindakan guru dalam upaya memperbaiki aktifitas dan meningkatkan hasil belajar siswa ini diwujudkan dengan memilih metode diskusi melalui lembar kerja siswa (LKS). Dengan metode ini siswa dituntut terampil melakukan diskusi dalam proses menemukan konsep melalui studi pustaka dan diskusi sesuai dengan petunjuk LKS.

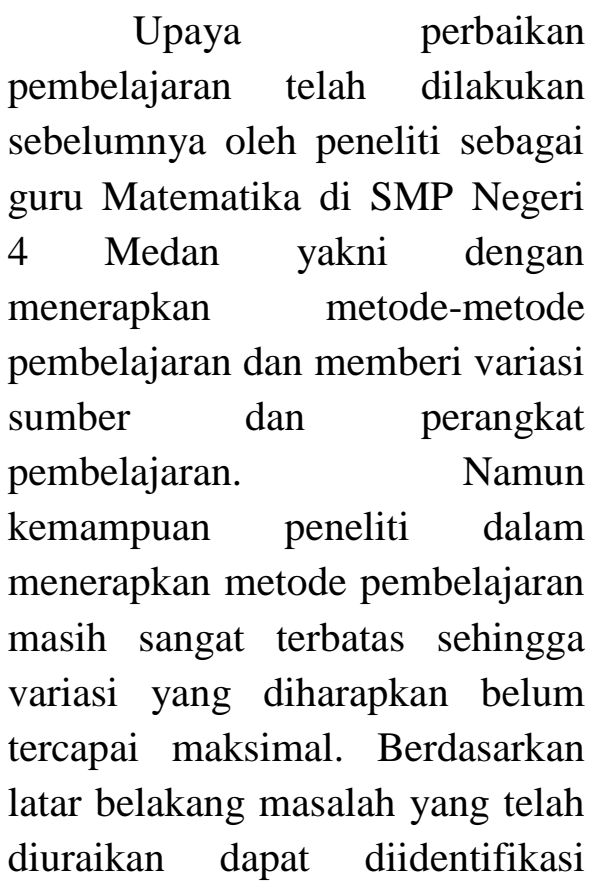


permasalahan yang relevan terhadap pembelajaran Bahasa Indonesia di SMP Negeri 4 Medan diantaranya : (1) Pembelajaran Matematika kurang menyentuh pengalaman seharihari siswa, (2) Pembelajaran masih monoton karena keterbatasan kemampuan peneliti dalam menerapkan variasi model dan metode pembelarajan, (3) Interaksi belajar siswa dengan sumber belajar masih lemah atau pembelajaran tidak berorintasi aktivitas siswa, (4) Keterbatasan sumber dan perangkat pembelajaran dalam menerapkan pembelajaran berorientasi aktivitas siswa. Berdasarkan identifikasi masalah, rumusan masalah adalah : (1) Bagaimana hasil belajar psikomotorik siswa selama pembelajaran dengan menerapkan metode diskusi berbantuan LKS pada bidang studi Matematika di kelas VIII-2 SMP Negeri 4 Medan? Bagaimana hasil belajar afektif siswa selama pembelajaran dengan menerapkan metode diskusi berbantuan LKS pada bidang studi Matematika di kelas VIII-2 SMP Negeri 4 Medan? (3) Bagaimana hasil belajar kognitif siswa selama pembelajaran dengan menerapkan metode diskusi berbantuan LKS pada bidang studi Matematika di kelas VIII-2 SMP Negeri 4 Medan?

Adapun tujuan penelitian yang akan dicapai adalah (1) Untuk megetahui hasil belajar psikomotorik siswa setelah pembelajaran dengan menerapkan metode diskusi berbantuan LKS pada bidang studi Matematika di kelas VIII-2 SMP Negeri 4 Medan. (2) Untuk mengetahui bagaimana hasil belajar afektif siswa setelah pembelajaran dengan menerapkan metode diskusi berbantuan LKS pada bidang studi Matematika di kelas VIII-2 SMP Negeri 4 Medan. (3) Untuk mengetahui bagaimana hasil belajar kognitif siswa setelah pembelajaran dengan menerapkan metode diskusi berbantuan LKS pada bidang studi Matematika di kelas VIII-2 SMP Negeri 4 Medan.

\section{METODOLOGI PENELITIAN}

Penelitian ini akan dilaksanakan SMP Negeri 4 Medan yang beralamat di Jalan Jati III No. 18 Kelurahan Teladan Timur. Penelitian ini dilaksanakan pada semester ganjil Tahun Pelajaran 2014/2015 selama 4 (bulan) bulan mulai dari bulan September sampai dengan Desember 2014. Pengambilan data dilaksanakan selama 4 (empat) KBM yang dibagi dalam 2 (dua) Siklus. Subjek penelitian ini adalah siswa kelas VIII-2 SMP Negeri 4 Medan yang berjumlah 34 siswa. Penelitian ini berbentuk Penelitian Tindakan Kelas (PTK). Penelitian tindakan kelas adalah penelitian yang dilakukan oleh guru di kelas atau di sekolah 
dengan penekanan pada penyempurnaan atau peningkatan proses pembelajaran. Dalam satu siklus terdiri atas empat langkah, yaitu perencanaan (planning), tindakan (acting), observasi (observing) dan refleksi (reflecting).

\section{HASIL PENELITIAN DAN PEMBAHASAN}

Kondisi awal siswa VIII-2 yang menyangkut hasil belajar siswa pada mata pelajaran Matematika. Untuk mempertegas indentifikasi tersebut dilaksanakan Pretes. Data Pretes menunjukkan nilai terendah 40 dan tertinggi 60 dengan rata-rata 48 dan KKM 75 sehingga ketuntasan belajar secara kalsikal $0 \%$. Atau kemampuan awal siswa sangat rendah mengindikasikan bahwa siswa tidak membaca buku di rumah untuk materi yang akan dipelajari di sekolah.

\section{Hasil Penelitian Siklus I}

Penilaian

aktivitas

diperoleh dari lembar observasi aktivitas dilakukan pada saat siswa bekerja dalam kelompok diskusi. Pengamatan dilakukan oleh dua pengamat selama 20 menit kerja kelompok dalam setiap kegiatan belajar mengajar (KBM). Hasil observasi aktivitas siswa disajikan dalam tabel 1 .
Tabel 1. Skor Aktivitas

Psikomotorik Siswa Siklus I

\begin{tabular}{|c|c|c|c|}
\hline No & Psikomotorik & Skor & Proporsi \\
\hline 1 & $\begin{array}{l}\text { Mengidentifikasi maksud } \\
\text { pembicaraan }\end{array}$ & 27 & $31 \%$ \\
\hline 2 & $\begin{array}{l}\text { Menggunakan tata bahasa } \\
\text { yang tepat }\end{array}$ & 28 & $32 \%$ \\
\hline 3 & $\begin{array}{l}\text { Berbicara jelas dan mudah } \\
\text { dimengerti }\end{array}$ & 19 & $22 \%$ \\
\hline 4 & $\begin{array}{ll}\text { Menggunakan } & \text { pilihan } \\
\text { kosakata yang tepat } & \\
\end{array}$ & 29 & $33 \%$ \\
\hline 5 & $\begin{array}{l}\text { Intonasi suara sesuai yang } \\
\text { disampaikan }\end{array}$ & 20 & $23 \%$ \\
\hline
\end{tabular}

Selain hasil belajar psikomotorik, guru juga meneliti perkembangan afektif siswa. Untuk merekam afektif siswa dilakukan oleh seorang pengamat sesuai dengan instruksi oleh peneliti. Hasil rekaman yang dilakukan oleh pengamat diserahkan kembali kepada peneliti.

Tabel 2. Skor Aktivitas Belajar Afektif Siklus I

\begin{tabular}{|c|l|c|c|}
\hline No & \multicolumn{1}{|c|}{ Afektif } & Skor & Proporsi \\
\hline 1 & Kejujuran & 23 & $26 \%$ \\
\hline 2 & Disiplin & 26 & $30 \%$ \\
\hline 3 & Tanggung jawab & 25 & $28 \%$ \\
\hline 4 & Ketelitian & 28 & $32 \%$ \\
\hline 5 & Kerjasama & 21 & $24 \%$ \\
\hline
\end{tabular}

Pada akhir proses belajar mengajar siswa diberi tes hasil belajar sebagai Postes I dengan tujuan untuk mengetahui tingkat keberhasilan siswa dalam proses belajar mengajar yang telah dilakukan pada Siklus I. Adapun data hasil penelitian pada Siklus I disajikan dalam Tabel 3. 
Tabel 3 Deskripsi Data Hasil Tes Siklus I

\begin{tabular}{|c|l|c|c|}
\hline No & Psikomotorik & Skor & Proporsi \\
\hline 1 & $\begin{array}{l}\text { Mengidentifikasi } \\
\text { maksud pembicaraan }\end{array}$ & 47 & $59 \%$ \\
\hline 2 & $\begin{array}{l}\text { Menggunakan tata } \\
\text { bahasa yang tepat }\end{array}$ & 48 & $60 \%$ \\
\hline 3 & $\begin{array}{l}\text { Berbicara secara jelas } \\
\text { dan mudah dimengerti }\end{array}$ & 42 & $53 \%$ \\
\hline 4 & $\begin{array}{l}\text { Menggunakan pilihan } \\
\text { kosakata yang tepat }\end{array}$ & 47 & $59 \%$ \\
\hline 5 & $\begin{array}{l}\text { Intonasi suara sesuai } \\
\text { yang disampaikan }\end{array}$ & 44 & $57 \%$ \\
\hline
\end{tabular}

Siswa dengan nilai terendah 60 sebanyak 12 siswa dan yang mendapat nilai 100 sebanyak 7 orang. Nilai rata-rata 77 dengan KKM 75, jumlah siswa tuntas 22 dari 34 siswa. Hal ini menunjukkan pengetahuan kognitif siswa masih rendah. Hasil tersebut menunjuk/kan bahwa pada Siklus I secara klasikal siswa belum tuntas belajar, karena siswa yang memahami materi yang telah disampaikan hanya sebesar $64 \%$ lebih kecil dari persentase ketuntasan yang dikehendaki yaitu sebesar $85 \%$. Hal ini disebabkan karena siswa masih merasa baru dan belum mengerti apa yang dimaksudkan dan digunakan guru dengan menerapkan LKS dalam pembelajaran diskusi.

\section{Refleksi Siklus I}

Dalam pelaksanaan kegiatan belajar mengajar diperoleh informasi dari hasil pengamatan sebagai berikut: a. LKS belum berfungsi optimal mengarahkan kegiatan belajar siswa sehingga aktifitas belajar siswa belum sepenuhnya dapat diarahkan melalui LKS.

b. Pembelajaran secara kombinasi klasikal, kelompok dan individu dalam diskusi dan latihan belum maksimal.

c. Keaktifan siswa dalam diskusi kelompok belum tampak, lebih banyak kegiatan baca tulis.

d. Gerakan guru mendekati untuk membimbing siswa belum merata.

e. Siswa banyak bertanya dan mengungkapkan hal-hal yang menyimpang dari pembahasan.

\section{Hasil Penelitian Siklus II}

Aktivitas siswa pada Siklus II mengalami peningkatan dibandingkan Siklus I. Hasil pengamatan aktivitas belajar siswa pada siklus II disajikan pada tabel 4.

Tabel 4. Skor Aktivitas Belajar Psikomotorik Siswa Siklus II

\begin{tabular}{|c|c|c|c|}
\hline Nilai & Frekuensi & Ketuntasan & Rata-rata \\
\hline 100 & 7 & $20 \%$ & \multirow{2}{*}{7} \\
\cline { 1 - 3 } & 15 & $44 \%$ & \multirow{2}{*}{7} \\
\cline { 1 - 3 } 60 & 12 & - & \\
\hline Jumlah & 34 & $64 \%$ & \\
\hline
\end{tabular}

Hasil belajar afektif siswa juga mengalami peningkatan, adapun data peningkatannya disajikan dalam tabel 5. 
Tabel 5 Skor Aktifitas Belajar

Afektif Siswa Siklus II

\begin{tabular}{|l|l|c|c|}
\hline No & Afektif & Skor & Proporsi \\
\hline 1 & Kejujuran & 46 & $58 \%$ \\
\hline 2 & Disiplin & 43 & $54 \%$ \\
\hline 3 & Tanggung jawab & 45 & $56 \%$ \\
\hline 4 & Ketelitian & 43 & $54 \%$ \\
\hline 5 & Kerjasama & 45 & $56 \%$ \\
\hline
\end{tabular}

Pada akhir proses belajar mengajar Siklus II siswa diberi tes hasil belajar segagai Postes II dengan tujuan untuk mengetahui tingkat keberhasilan siswa dalam proses belajar mengajar yang telah dilakukan pada Siklus II. Adapun data hasil penelitian pada Siklus II disajikan dalam Tabel 6.

Tabel 6 Deskripsi Data Hasil Tes Kognitif Siklus II

\begin{tabular}{|c|c|c|c|}
\hline Nilai & Frekuensi & Ketuntasan & $\begin{array}{c}\text { Rata- } \\
\text { rata }\end{array}$ \\
\hline 100 & 13 & $38 \%$ & \multirow{2}{*}{86} \\
\cline { 1 - 3 } 80 & 18 & $53 \%$ & \multirow{2}{*}{86} \\
\hline 60 & 3 & - & \\
\hline Jumlah & 34 & $91 \%$ & \\
\hline
\end{tabular}

Merujuk pada Tabel 4.6. Siswa dengan nilai terendah 60 sebanyak 3 siswa dan yang mendapat nilai tertinggi 100 sebanyak 13 orang. Nilai rata-rata 86 dengan jumlah siswa tuntas 31 orang. Hal ini menunjukkan hasil belajar kognitif siswa mulai membaik. Hasil tersebut menunjukkan bahwa pada Siklus II secara klasikal siswa sudah tuntas belajar, karena siswa yang memahami materi yang telah disampaikan hanya sebesar $91 \%$ mencapai persentase ketuntasan yang dikehendaki yaitu sebesar $85 \%$. Hal ini disebabkan karena siswa sudah mulai beradaptasi dengan apa yang dimaksudkan dan digunakan guru dengan menerapkan LKS dalam diskusi.

\section{Pembahasan}

Pembahasan terhadap permasalahan penelitian maupun hipotesis tindakan berdasarkan analisis data kualitatif hasil penelitian dari kerja kolaborasi antara peneliti, guru sejawat dan pembimbing penelitian yang terlibat dalam kegiatan ini, sebelum dan sesudah penelitian yang dibuat oleh guru yang melakukan tindakan kerja kolaborasi dimulai: 1) dialog awal, 2) perencanaan tindakan, a) identifikasi masalah yang diduga mempengaruhi hasil belajar siswa dan penyebabnya; b) perencanan solusi masalah, 3) pelaksanaan tindakan, dan 4) evaluasi hasil pelaksanaan tindakan.

Perbaikan kualitas proses dan hasil belajar ditunjukkan melalui data kognitf, psikomotorik dan afektif siswa. Merujuk pada Gambar 4.1. menunjukkan peningkatan kualitas psikomotorik belajar siswa dari siklus I ke siklus II. Keterampilan mengidentifikasi maksud pembicaraan naik dari $31 \%$ menjadi $59 \%$, menggunakan tata bahasa yang tepat naik dari $32 \%$ menjadi $60 \%$, berbicara 
secara jelas dan mudah dimengerti meningkat dari $22 \%$ menjadi $53 \%$, menggunakan pilihan kosakata yang tepat meningkat dari $33 \%$ menjadi $59 \%$ dan Intonasi suara sesuai dengan yang disampaikan meningkat dari $23 \%$ menjadi $57 \%$ kondisi ini sudah lebih baik dan menuju yang diharapkan karena seharusnya semua aspek psikomotorik harus meningkat dan siswa juga sudah terbiasa dengan metode pembelajaran.

Berdasarkan pada gambar 4 menunjukkan bahwa peningkatan hasil belajar afektif siswa dari siklus I dan siklus II. Aspek kejujuran menunjukkan peningakatan yang paling dominan yaitu dari $26 \%$ menjadi $58 \%$, hal ini disebkan guru selalu memberikan motivasi kepada siswa disaat awal pembelajaran untuk selalu jujur dalam segala hal, termasuk dalam belajar. Aspek tanggung jawab juga mengalami peningkatan yang signifikan yaitu dari $30 \%$ menjadi $54 \%$, hal ini disebabkan setiap akhir diskusi siswa diruh untuk mempertangggung jawabkan hasil diskusinya. Selain itu kerjasama siswa juga meningkat dari $28 \%$ menjadi $56 \%$, ketelitian dari $33 \%$ menjadi $54 \%$ dan disiplin dari $24 \%$ menjadi $56 \%$.

Merujuk pada Gambar 3 data kemampuan awal menunjukan tidak seorang siswapun mendapat nilai diatas KKM sehingga ketuntasan $0 \%$ dengan rata-rata 48. Pada formatif I menunjukkan, hanya 22 dari 34 siswa memenuhi kriteria ketuntasan minimal (KKM) sebesar 75, siswa yang telah tuntas sebanyak 64\%. Sehingga pembelajaran Siklus I dikatakan gagal memberi ketuntasan secara klasikal karena kurang dari $85 \%$ siswa memperoleh nilai $\geq 68$.

Kendala pada Siklus I yang ditindak lanjuti di Siklus II telah menunjukkan peningkatan yang berarti dalam perolehan skor. Hal ini nampak pada perolehan data pada Gambar 6 dimana siswa yang tuntas mengalami kenaikan, dari 22 siswa di Siklus I menjadi 31 siswa yang tuntas di Siklus II, jadi sekitar $91 \%$ telah tuntas. Karena ketuntasan klasikal telah melampaui $85 \%$ maka KBM Siklus II dikatakan berhasil meningkatkan hasil belajar siswa sampai pada ketuntasan klasikal yang diharapkan.

Peningkatan hasil belajar sehingga tuntas klasikal pada Siklus II ini diperoleh dari tindakan perbaikan pada Siklus II diantaranya :
a. Lebih mengoptimalkan penggunaan LKS dalam mengarahkan kegiatan siswa karena LKS telah disusun secara matang dengan harapan aktifitas siswa dapat terarah.

b. Pembelajaran akan berorientasi pada kelompok kooperatif saja untuk 
diskusi karena memerlukan

lebih banyak waktu menempuh ketiga orientasi klasikal, kelompok dan individual sekaligus.

c. Guru membimbing siswa secara merata untuk mempermudah siswa melakukan diskusi dan meningkatkan minat siswa sehingga menekan aktifitas baca tulis dan bertanya pada guru untuk hal-hal yang menyimpang dari pembahasan.

d. Memilih ketua kelompok diskusi untuk mengatasi waktu pembimbingan yang kurang dimana fungsi ketua kelompok diskusi adalah sebagai pengganti guru dalam diskusi kelompok yang berasal dari siswa.

e. Guru menganalisis kembali kemampuan penerapan model dan materi ajar dengan memperkirakan kesulitan-kesulitan yang akan dihadapi siswa dan jalan keluar langsung yang dapat ditempuh ditengah KBM berlangsung.

Secara keseluruhan pelaksanaan proses pembelajaran yang dilakukan oleh peneliti sudah sesuai dengan harapan, karena sudah menggunakan metode diskusi berbantuan LKS dengan baik dan benar. Sehingga siswa memiliki minat dalam belajar berkaitan dengan tindak mengajar yang dilakukan peneliti sebagai guru di kelas adalah selalu memberikan tujuan pembelajaran, inti materi ajar dan kegiatan yang akan dilakukan, membimbing dan mengarahkan siswa melalui LKS yang bertujuan menciptakan hubungan baik dengan siswa, mendorong dan membimbing siswa dalam menyampaikan ide, berlaku adil pada semua siswa, mengingatkan siswa untuk mengulangi materi yang telah diajarkan, memberi semangat siswa dalam belajar, menciptakan suasana yang membuat siswa terlibat secara aktif dengan memberi latihan soal-soal.

Proses pembelajaran yang dilakukan dengan gaya mengajar terbuka merupakan upaya pembenahan gaya mengajar guru. Pembenahan yang diupayakan antara lain model pembelajaran klasikal, yang cenderung dilaksanakan tanpa variasi dibenahi menjadi model belajar diskusi kelompok kooperatif berbantuan LKS. Pembenahan ini dilaksanakan dengan strategi pembelajaran terbuka, yaitu menjamin rasa aman, nyaman dan senang dalam pembelajarannya serta guru selalu menarik dan memelihara minat belajar siswa.

Tindakan mengajar yang sesuai dengan harapan seperti yang telah dilaporkan dapat menjawab rumusan msalah. Beberapa tindak mengajar tersebut merupakan tindakan guru yang merupakan kunci 
keberhasilan atau memberikan hasil yang memuaskan dan dipandang memberikan kontribusi yang cukup bagi keberhasilan usaha meningkatkan hasil belajar.

Melalui metode diskusi berbantuan LKS, perencanaan pembelajaran ini dapat dilaksanakan dengan baik. Hal itu ditunjukkan oleh hasil evaluasi pelaksanaan tindakan kelas yang dilaporkan terdahulu. Tindakan belajar dan mengajar seperti telah dilaporkan pada evaluasi tindakan kelas, menjawab rumusan masalah. Tindakan-tindakan guru tersebut memenuhi teori dalam menciptakan kondisi belajar yang kreatif.

\section{SIMPULAN DAN SARAN}

Dari hasil kegiatan pembelajaran yang telah dilakukan selama dua siklus, dan berdasarkan seluruh pembahasan serta analisis yang telah dilakukan dapat disimpulkan sebagai berikut:

a. Adanya peningkatan hasil belajar psikomotorik siswa yaitu menurut pengamatan pengamat pada siklus I dan II antara lain mengidentifikasi maksud pembicaraan $31 \%$ menjadi $59 \%$, menggunakan tata bahasa yang tepat $32 \%$ menjadi 60\%, berbicara secara jelas dan mudah dimengerti $22 \%$ menjadi $53 \%$, menggunakan pilihan kosakata yang tepat 33\% menjadi 59\%, dan yang intonasi suara sesai dengan yang disampaikan $23 \%$ menjadi $57 \%$.

b. Data hasil belajar afektif siswa mengalami peningkatan yaitu menurut pengamatan pengamat pada Siklus I dan II antara lain kejujuran $26 \%$ menjadi $58 \%$, disiplin $30 \%$ menjadi $54 \%$, tanggung jawab $28 \%$ menjadi $56 \%$, ketelitian $32 \%$ menjadi $54 \%$, dan kerjasama $24 \%$ menjadi $56 \%$.

c. Hasil penelitian menunjukkan bahwa metode diskusi berbantuan LKS dapat meningkatkan ketuntasan pembelajaran siswa, terbukti dari hasil tes siswa ketuntasan pembelajaran meningkat. Pada Siklus I rata-rata nilai tes 77 dengan ketuntasan pembelajaran sebesar $64 \%$ dan pada Siklus II rata-rata nilai tes 91 dengan ketuntasan pembelajaran naik menjadi 91\%, sehingga berhasil memberikan ketuntasan hasil belajar secara klasikal.

\section{DAFTAR RUJUKAN}

Aunurrahman. 2009. Belajar dan Pembelajaran, Bandung: Alfabeta Bandung. 
Herlanti, Y. 2006. Tanya Jawab Seputar Penelitian Pendidikan Sains. Jakarta: UIN Syarif Hidayatullah.

Joyce, Wheil, dan Calhoun. 2010. Model's of Teaching (Model-Model Pengajaran). Yogyakarta: Pustaka Pelajar.

Majid, A. 2009. Perencanaan Pembelajaran. Bandung: Rosda.

Sardiman, A, M. 2006. Interaksi dan Motivasi Belajar Mengajar. Jakarta: Raja Grafindo Persada.
Sudjiono, A. 2008. Pengantar Evaluasi Pendidikan. Jakarta: Raja Grafindo Pustaka.

Wena, M. 2009. Strategi Pembelajaran Inovatif Kontemporer. Jakarta: Bumi Aksara.

B, Nurmi. 2015. Perbaikan Kemampuan Psikomotorik Siswa Melalui Metode Diskusi Berbantuan LKS Pada Mata Pelajaran Matematika Di Kelas VIII-2 SMP Negeri 4 Medan. (PTK) Kalangan Sendiri. 